\title{
Natural Regeneration of the Mangrove Vegetation on Abandoned Salt Ponds in Ceará, in the Semi-Arid Region of Northeastern Brazil
}

\author{
Armando Soares dos Reis-Neto ${ }^{1, *(\mathbb{D}}$, Antonio Jeovah de Andrade Meireles ${ }^{2}{ }^{(\mathbb{C}}$ and \\ Marília Cunha-Lignon ${ }^{3}$ (D) \\ 1 Energy and Environment Institute, Graduate Program in Environmental Sciences (PROCAM), University of \\ São Paulo (USP), São Paulo, SP 05508-010, Brazil \\ 2 CNPq Research Productivity Fellow; Graduate Program in Geography at Universidade Federal do \\ Ceará/UFC, Fortaleza, CE 60455-900, Brazil; meireles@ufc.br \\ 3 Registro Experimental Campus, São Paulo State University (UNESP), Registro, SP 11900-000, Brazil; \\ cunha.lignon@unesp.br \\ * Correspondence: armandoreisneto@gmail.com or armando@alumni.usp.br; Tel.: +55-119-810-50817
}

Received: 5 December 2018; Accepted: 15 February 2019; Published: 23 February 2019

\begin{abstract}
The development of the mangrove in Ceará state, northeastern Brazil, is limited by local environmental and climatic factors, associated with the variables that determine the region's semi-arid climatic conditions. The same conditions also contribute to the installation of artisanal saltworks in estuarine environments. The artisanal production of salt peaked in the 20th century, but with the decline of this activity, the salt evaporation ponds were abandoned, and have been incorporated back into the natural marine-estuarine environment and colonized by mangrove forests. In the early 2000s, however, the expansion of shrimp farming operations impacted this same environment. The present study was based on a spatiotemporal analysis of the natural regeneration of the mangrove vegetation in abandoned salt pond areas in the Brazilian semi-arid region between 1968 and 2009. The integrated analysis of mangrove ecosystem dynamics and the legislation that regulates the licensing of these economic activities identified a number of technical problems in the formulation and execution of the COEMA resolution 02/2002, which permits the installation of shrimp farms in areas dominated by the mangrove. The findings of the present study reinforce the need for a careful reformulation of the Ceará state environmental legislation, in order to guarantee the maximum possible conservation of the coastal zone.
\end{abstract}

Keywords: historical ecology; integrated analysis; geotechnology; environmental dynamics; habitat regeneration

\section{Introduction}

Mangrove ecosystems are found in the intertidal zone of tropical and subtropical coasts, where the vegetation may be arboreal, shrubby, or low-lying, depending on the climate, and the prevailing environmental and ecodynamic conditions. The global distribution, structure, and functions of mangroves are determined by climatic drivers (e.g., water temperature and rainfall regimes). Mangrove forests develop best in regions where rainfall is more regular, temperatures are higher, cloud cover is reduced, and hurricanes or typhoons are rare [1]. Mangroves are well-adapted for survival in the intertidal zone, considering the constant variation in salinity, inundation, and the availability of nutrients, which together contribute to the biocomplexity of this ecosystem, which provides essential services [2]. The coastline of Brazil is $8500 \mathrm{~km}$ long, and mangroves are found along approximately $80 \%$ of this coast, from Oiapoque, at the northernmost extreme of the country, in the state of Amapá 
$\left(4^{\circ} 30^{\prime} \mathrm{N}\right)$, to the southern limit of the distribution of mangrove ecosystems on the Atlantic coast of South America, at the Santo Antônio Lagoon $\left(28^{\circ} 28^{\prime}\right.$ S) in Santa Catarina state [3,4]. The estimated area of mangroves in Brazil is currently 1,398,966.13 hectares, of which 497,503.37 hectares are protected by federal or state conservation units [5]. To better understand the distribution of mangrove forests in Brazil, Schaeffer-Novelli et al. [6] proposed the division of the country's coast into eight sectors, defined by their environmental conditions and morphological similarities. Sector IV in this classification, which includes the state of Ceará $\left(02^{\circ} 46^{\prime} \mathrm{S}\right)$, is dominated by strong tides and a predominantly rectilinear coast which, in addition to mangroves, has sandy beaches, rocky outcrops, dunes, and cliffs.

In the past, local conditions, such as the region's semi-arid climate, high temperatures $\left(>28^{\circ} \mathrm{C}\right)$, high potential evaporation rates, and the availability of water in the local estuaries all contributed fundamentally to the construction of saltworks on the coast of northeastern Brazil [7]. The solar salt evaporation ponds installed in the coastal zone were concentrated in the supratidal zone [8]. The salt is produced by a simple system, based on the evaporation of the sea water retained in the evaporation ponds, or salt pans. The salinity in each pond is kept in equilibrium by the factors that limit saturation, which are essentially constant. The evaporation ponds are typically associated with other infrastructure, including areas for the collection, grinding, and stockpiling of the salt precipitated in the ponds. All this infrastructure is typically found within the estuarine environment, in areas that were once covered in mangrove forest.

Many of the largest cities in the Brazilian Northeast are located in estuarine environments, and in many cases, the zone of urban development has expanded into areas adjacent to the old saltworks built along the river margins. The local estuaries have been occupied by the salt-making industry since the 16th century, but many of these areas were converted into shrimp farms during the 20th century. Most of this infrastructure has been installed in areas once dominated by mangrove forests. Nowadays, most salt extraction is mechanized, although the Brazilian Northeast is still the country's principal salt-producing region, accounting for $95 \%$ of its production of sea salt [9].

Resolution number 02/2002 of the Ceara State Environment Council (COEMA) states that (article 1, paragraph XII): "Salt works: are man-made areas that generate ecosystems with residual hypersalinity in the soil, and as a consequence, a reduced capacity for the natural regeneration of the mangrove vegetation" [10]. Article 7 of the same resolution supports the conversion of these unused (or abandoned) salt ponds into shrimp farms [10].

Despite the historical importance of the extraction of salt by solar evaporation in the Brazilian Northeast, the artisanal industry declined drastically during the second half of the 20th century. With the modernization of the salt-making industry, and the declining importance of the product in the regional economy, most artisanal saltworks were abandoned, allowing the mangrove to expand back into these areas. The regeneration of the mangrove in abandoned saltworks has been observed at a number of locations along the northeastern Brazilian coast [11-14]. Despite the evidence on the regeneration of the mangrove vegetation in abandoned salt ponds, the environmental legislation of the state of Ceará does not contemplate the potential regeneration of the mangrove ecosystem in its regulatory mechanisms for the licensing of shrimp farming operations in the intertidal zone of estuaries. This has permitted the occupation of abandoned saltworks for the installation of shrimp farms.

The present study analyzed the spatiotemporal evolution of natural mangrove regeneration on abandoned saltworks areas in the semi-arid northeastern Brazilian state of Ceará. The study adopted an integrated, socio-environmental approach, which included an evaluation of the environmental legislation of the state of Ceará, specifically, Ceará State Council for Environmental Policy and Management (COEMA) resolution number 02/2002 [10] that refers to the licensing of shrimp farming operations in the state. The approach adopted here aimed to contribute to sustainable management and to the conservation of estuarine environments. It focuses primarily on the potentiality of geo-environmental functions and ecosystem services provided by mangrove regeneration in abandoned saltworks areas $[15,16]$. The present study highlights the environmental and historical importance of the regeneration of the mangrove in the area of abandoned salt ponds, and the resilience 
of this ecosystem. This characteristic is fundamentally important for the sustainable, long-term management of these environments, in particular within a scenario of climate change, which has profound consequences for coastal areas. In this context, we discuss the state law that encourages the conversion of these areas into shrimp farms or saltworks, considering them to be unproductive, abandoned, or ecologically defunct.

\section{Location of the Study Area and Methods}

The Brazilian state of Ceará is part of the country's semi-arid Northeast, which is characterized by a natural deficiency of freshwater. The hydrological cycle of the rivers that flow into the state's coast is determined primarily by precipitation patterns [17]. In 2010, the aquifer recharge was one of the smallest in recorded history, and had a serious impact on freshwater reserves during the five dry years that followed 2011, that is, between 2012 and 2016 [18]. The region's rainy season (when 90\% of the annual precipitation is recorded in the first semester, and historical average of $800 \mathrm{~mm}$ ) lasts from February to May, although, between 2010 and 2016, the lowest annual mean precipitation-only $405 \mathrm{~mm}$-was recorded. The dry season peaks between August and November [19,20]. This prolonged dry season provides ideal conditions for the production of salt by the evaporation of seawater. The region's mean tidal amplitude is $2 \mathrm{~m}$, increasing to $2.6 \mathrm{~m}$ on the spring tide. This sector of the coast provides intermediate conditions for the development of mangroves, given the reduced availability of freshwater from rainfall and fluvial discharge, and the high concentrations of salt found in the water and sediments of the local estuaries, which limit the potential for the growth of the mangrove [6,21].

The lower Ceará River forms the boundary between the municipalities of Fortaleza and Caucaia, and its estuary $\left(03^{\circ} 44^{\prime} \mathrm{S}, 38^{\circ} 39^{\prime} \mathrm{W}\right)$ has been designated an Environmental Protection Area, known as APA do Rio Ceará, as shown in Figure 1. This is a sustainable-use conservation unit, which is managed by the Ceará State Council for Environmental Policy and Management (CONPAM). The unit was created by Ceará State decree number 25,413/1999 and covers an area of 2744.89 ha.



Figure 1. Location of Ceará River estuary, the Margarida salt pond, and the limits of the Ceará River Environmental Protection Area (APA do Rio Ceará). 
The Ceará River presents a number of unique environmental and social features along its course. Part of the middle and lower Ceará is integrated with the indigenous lands of the Tapeba ethnicity, which has guaranteed the conservation of areas of gallery forest and coastal floodplains with mangrove forest. One other important feature of local land use and occupation is the presence of abandoned saltworks. The focus of the present study is the Salina Margarida, an abandoned saltworks located on the left margin of the Ceará River, near its mouth, as shown in Figure 1. The production and extraction of salt at this site was deactivated in the 1970s, enough time for the mangrove vegetation to reoccupy much of the area that was originally deforested, although the remains of the levees used to demarcate the evaporation ponds can still be observed within the area [13].

The typical mangrove vegetation present in the Ceará River are consisted of four species, in three genera. These species are the red mangrove, Rhizophora mangle L., the white mangrove, Laguncularia racemosa, (L.) Gaertn, F., and the black mangroves, Avicennia germinans, Stapf. \& Leechman and Avicennia schaueriana, Stapf. \& Leechman. A fifth species, the buttonwood, Conocarpus erectus L., is also associated with the mangrove ecosystem [14]. Field work has been made to describe species composition and distribution along the study area.

\subsection{Remote Sensing and Mangrove Vegetation Structure}

In recent decades, geotechnology, including remote sensing and cartography, have played a fundamental role in the mapping and analyzing of changes in landscape and the spatial dynamics of natural environments, related to both natural catastrophes and human pressures [22]. Freitas and Tagliani [23] concluded that, to guarantee the better integration of traditional and scientific knowledge, and territorial planning, it is essential to integrate the available data through information and communication technologies, in particular, geographic information systems (GISs). Spatial information systems provide an important tool for the integration, manipulation, and visualization of the different perspectives of the available quali-quantitative geo-environmental approaches.

The present study was based on the processing and georeferencing of satellite images and aerial photographs, using remote sensing techniques. The images were selected based on the lowest possible cloud cover. The material included a panchromatic aerial photograph (1:70,000 scale), obtained by the Atlântico Sul aerial survey company dated from 1968. This photograph is part of the collection of images held by the Department of Geography at the Federal University of Ceará (UFC) in Fortaleza. The spatiotemporal analysis focused on LANDSAT 5 EMT satellite images from 19/06/1997, provided by the Brazilian National Institute for Space Research (INPE), in color spectral bands 5, 4, and 3 in the RGB system (red, green, and blue). The analyses also used high resolution images (QuickBird and IKONOS) from 2009, available in the current version of Google Earth Pro ${ }^{\circledR}$. All images were processed in Quantum GIS ${ }^{\circledR} 1.7$ (QGIS Open Source Geospatial Foundation Project). Ground truth geographic coordinates were taken by GPS to reference a unified GIS layout, in which all three images were overlapped, with each image being adjusted to a standard scale, to guarantee reliable data comparisons. Conventional digital image techniques were used, divided into preprocessing, enhancement, and classification, according to Jensen [24]. The preprocessing was not used, while in the enhancement, the contrast stretch was used, changing the shape of the histogram and increasing the contrast of the image, in order to improve this quality.

The GIS analyses covered a total of 41 years, which was divided into period I (1968-1997) and period II (1997-2009). The processing of the images permitted the manual delimitation of the areas of mangrove forest and abandoned salt ponds at each year $(1968,1997$, and 2009), providing estimates of the area of each feature, in hectares. The cultural landscape of the estuarine complex of the Ceará River was evaluated using the hierarchical approach proposed by Schaeffer-Novelli et al. [3]. Guidelines for coastal management were derived from geoprocessing at a spatiotemporal scale [25], which permitted the visualization of the mangrove forest regeneration dynamics on abandoned saltworks, based on the classification of the landscape units defined as mangrove forest and abandoned saltworks, in 1968, 1997, and 2009. 
A 10-100 km resolution (setting level) was used for the analysis of the spatiotemporal variation of mangrove vegetation, providing the thematic classification of the two zones-mangroves and abandoned saltworks-as the basis for the classification of the area effectively regenerated (recovery of the vegetation area on the abandoned salt pond). The forest stand level (0.1-100 ha) was considered specifically for the analysis of the recuperation of the mangrove forest at the Margarida saltworks. For this, six plots were demarcated, and data were collected on the vegetation structure, using the approach of Schaeffer-Novelli [26], which consists of the diameter at breast height (DBH) of the trees, their vertical linear height, and species composition. The DBH was obtained using a Forestry Suppliers metric diameter tape, allowing direct measurement of the trunk's diameter. The trunk condition (alive or dead) was registered. Posteriorly, the mean height, basal area dominance, and stem density was calculated. These data were integrated with the analyses of the vegetation's growth.

\subsection{Analysis of the State Legislation}

The cultural landscape of the Ceará River was analyzed together with the environmental analysis, providing an empirical perspective on the relationship between the natural dynamics of the mangrove ecosystem and the local model of socio-economic development. This approach considered the environmental impacts of the abandoned saltworks and the use and occupation of salt flat areas, particularly in the context of shrimp farming operations. The studies of Meireles et al. [18,27] emphasize the need for the revision of the COEMA resolution 02/2002, which regulates shrimp farming operations in the state of Ceará.

\section{Results and Discussion}

\subsection{Analysis of the Spatiotemporal Evolution of the Mangroves of the Ceará River}

The QGIS ${ }^{\circledR}$ program provides a number of tools, and open-sharing mechanisms that permit all users to contribute to the formulation of the analysis. The use of free software for image processing permitted greater accessibility of the development of the geographic information system (GIS) platform. These tools were used to produce thematic maps, as shown in Figure 2a-c, that demonstrated the history of the landscape, in terms of the spatial dynamics of the mangrove and the abandoned saltworks. This analysis was organized into two periods, as described below. 


\section{Mangrove and Salt Works}

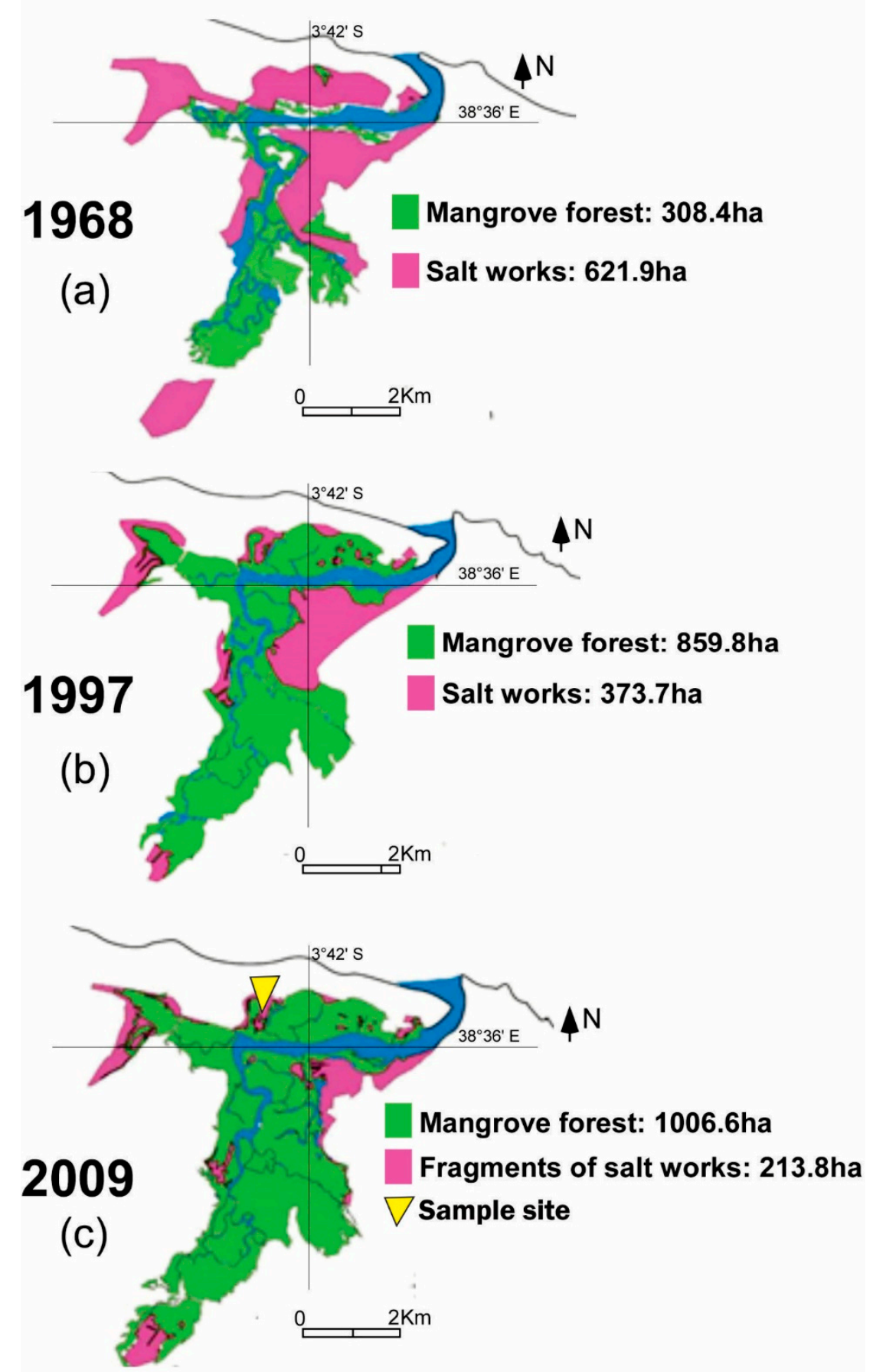

Figure 2. Thematic maps showing the areas of mangrove forest (in green) and the saltworks (in pink) in the estuary of the Ceará River in 1968 (a), 1997, (b) and 2009 (c). The figure shows in different periods how mangrove has expanded into abandoned salt work areas.

\subsubsection{Period I: $1968-1997$}

Artisanal solar evaporation saltworks were installed on the Ceará River at the beginning of the 20th century within mangrove areas. This economic activity flourished until the middle of the century, providing an important source of employment for the resident population. Following a decline in the price of salt, however, and the increasing competition from mechanized saltworks, the artisanal saltworks were abandoned in this region. In 1968, the abandoned saltworks of the Ceará estuary 
covered an area of 621.9 ha, as shown in Figure 2a, while the remaining mangrove forest covered a fragmented area of only 380.4 ha. Over the 29 years of period I, the mangrove forest cover increased by $126 \%$. The natural regeneration of the mangrove forest in the areas of abandoned saltworks resulted in the natural colonization of 248.2 ha, which represents a mean increase of 85.5 ha per decade. Despite the growth of the mangrove vegetation, which had expanded to 859.8 ha by 1997, as shown in Figure $2 b$, it was possible to confirm interference from the spread of urban development and the environmental impacts resulting from human activities within the estuarine zone. While private interests declined in the area, no evidence was found of any specific actions (in particular from public entities concerned with the environmental management of hydrographic basins) directed at the recuperation of the ecosystem to enable the re-establishment of its socio-environmental functions. Even the creation of the Ceará Estuary State Environmental Protection Area (APA do Rio Ceará) in 1999, resulted in the implementation of few practical measures for the conservation and management of the mangrove. During this 29 year period, the use of the land along the margins of the Ceará estuary, which was dominated by the salt-making industry in preceding decades, shifted to a scenario of urban and industrial expansion by the early 1990s.

\subsubsection{Period II: $1997-2009$}

This period was characterized by the continuing of the mangrove forest recuperation in the area of the abandoned saltworks, with an increase of 146.8 ha in the area of forest, with the area of the abandoned saltworks being reduced by approximately $66 \%$, to a total of only 213.8 ha by 2009 , as shown in Figure 2c. During period II, a mean increase of 133.25 ha was recorded per decade in the area of abandoned saltworks, an expansion approximately $55 \%$ greater than that recorded in period I. This natural regeneration of the mangrove forest may be related to the erosion of the levees that demarcated the evaporation salt ponds following the termination of salt production, and the re-establishment of tidal flow into these areas. This process may have resulted in more favorable conditions for the expansion of the mangrove since the end of the 1990s.

The total area covered by mangrove vegetation in the Ceará estuary in 2009 was estimated at approximately 1006.6 ha. Despite this advance in the area of mangrove forest, the ecological and morphodynamic (primarily, alterations in the hypersaline flats) components continue to suffer a process of degradation through urban expansion into the intertidal zone, the inadequate disposal of solid waste, and the discharge of domestic and industrial effluents directly into the river.

\subsubsection{Comparative analysis of periods I (1968-1997) and II (1997-2009)}

The comparative analysis of the vegetation dynamics over the 41 year study period revealed an expansion in the total area of mangrove in the Ceará estuary, from 380.4 ha to 1006.6 ha, as shown in Figure $2 \mathrm{a}, \mathrm{c}$, an increase of $165 \%$. By contrast, the area covered by saltworks decreased from 621.9 ha to $213.8 \mathrm{ha}$, as shown in Figure 2a,c, indicating that the mangrove vegetation had colonized naturally 408.1 ha of abandoned saltworks.

Figure 3 shows the growth in the area of mangrove, the reduction in saltworks, and the area colonized by mangrove within the study area. The most significant change in the area of mangrove was recorded between 1968 and 1997, when the forest increased 126\%, due primarily to the decline of the salt-making industry and the degradation of the structures (ponds, levees, and supply channels), which facilitated the natural regeneration of the mangrove. During period II, however, the mangrove grew at an even faster rate, probably due to the consolidation of environmental factors that provide ideal conditions for the expansion of the mangrove vegetation, principally within the area of the abandoned saltworks. 


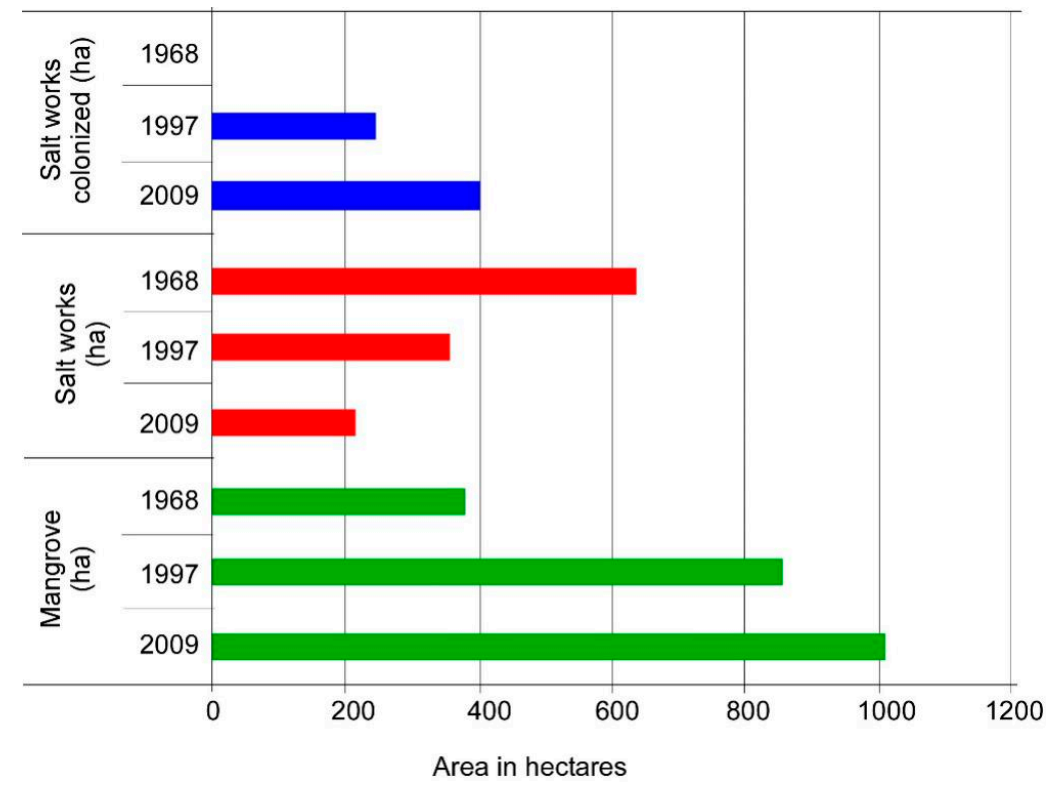

Figure 3. Evolution of the area in which the mangrove expanded, the saltworks decreased, and the mangrove forest colonized the abandoned saltworks (process of the regeneration of the mangrove between 1968 and 2009) in the Ceará estuary, in northeastern Brazil.

\subsection{Dynamics of the Mangrove Forest in the Area of the Margarida Saltworks}

During the eight years between 2004 and 2012, the mangrove forest expanded further within the area of the Margarida saltworks. With more favorable environmental conditions (both topographical and hydrological) for the re-establishment of the mangrove forest on the abandoned salt evaporation ponds, the vegetation expanded naturally through the recruitment of new individuals, with hydrochory and nutrient cycling being favored by the renewed tidal oscillation. The mangrove forest cover then underwent a process of expansion supported by the ecological succession of the habitat, initially through the recruitment of pioneer species (Batis maritima and Portulaca oleracea), and subsequently, through the establishment of a new configuration of mangrove species of intermediate or mature forest, as suggested by Reis-Neto et al. [14]. To characterize this process of natural succession, and the set of environmental components necessary for the development of the ecosystem, the recuperating mangrove forest found in the area previously occupied by saltworks was divided into two sectors: sector A (plots P1 and P2) and B (plots P3, P4, P5, and P6). In a general view, there is a decline of mangrove structure vegetation from P1 (near river's bank) to P6 (closer to the terrestrial portion). The mangrove structural development gradient is observed from a mature forest (Sector A) presenting higher DHB (>10 cm), higher height (maximum $16.8 \mathrm{~m}$.), and lower density (from 1333.33 to 2355.56 trunks $/$ ha), to an initial and intermediate growing forest (Sector B), presenting lower DHB $(<2.5 \mathrm{~cm})$, lower height (maximum $7.4 \mathrm{~m}$ ), and higher density (13,600-44,400 trunks/ha). The species dominance changes along the plots from areas dominated by R. mangle (P1 and P2), A. germinans (P3 and P4), and L. racemosa (P5 and $\mathrm{P} 6)$.

The vegetation expanded considerably between 2004 and 2009, with the mangrove forest extending up to $20 \mathrm{~m}$ into the area of the saltworks, and expanded a further $10 \mathrm{~m}$ between 2009 and 2012, as shown in Figure 4. The vegetation in the different tracts of expansion was characterized by the presence of distinct configurations of species identified in fieldwork: (i) the forest consolidated prior to 2004 was considered to be intermediate, with a mixed forest dominated by the black mangrove (A. germinans), with a smaller contribution of red mangrove (R. mangle); (ii) in the vegetation that colonized the Margarida saltworks by 2009, the forest is also defined as intermediate and mixed, with both black (A. germinans) and white (L. racemosa) mangrove, and (iii) the area colonized by 2012 was defined as initial forest, with a predominance of white mangrove (L. racemosa). 


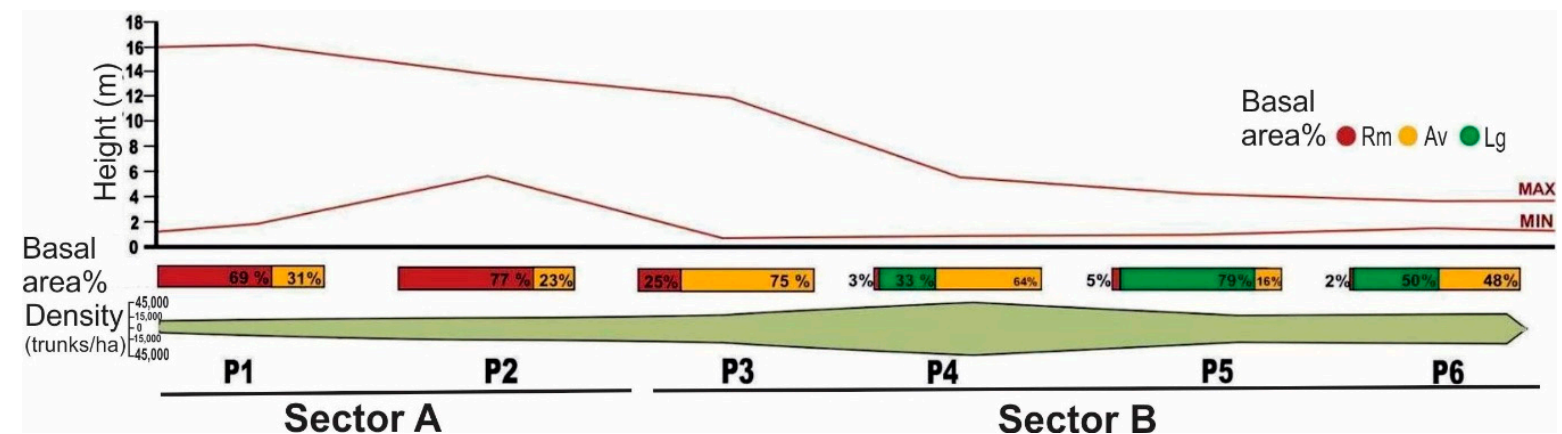

Figure 4. Graphic representation of the regeneration of the mangrove at Salina Margarida, showing the forest height in meters, and below the graph, bars showing the distribution of the basal area: red = R. mangle $(\mathrm{Rm})$, yellow $=A$. germinans $(\mathrm{Av})$, and green $=$ L. racemosa $(\mathrm{Lm})$. The mean density is also represented for each of the different sample areas (P1, P2, P3, P4, P5, and P6).

The saltwort (Batis maritima) and common purslane (Portulaca oleracea) are associated with the mangrove vegetation within the study area. These species were observed in the initial stages of colonization of the abandoned saltworks by the mangrove vegetation. These species are important for the initial establishment of the vegetation, and the creation of conditions appropriate for the recruitment of the mangrove propagules. The white mangrove, L. racemosa, is the pioneer tree species in this context, given its capacity for the rapid development and growth of its propagules and seedlings [28], and its resilience for the colonization of areas with impacted edaphic conditions [29], as in the case of abandoned saltworks. In the transition sector, which is more elevated topographically, buttonwood (Conocarpus erectus) trees can be observed growing along the brick wall of the abandoned saltworks, as shown in Figure 5. It was also possible to identify new zones of initial expansion of the mangrove vegetation into the area of the Margarida saltworks, in Figure 6, reinforcing the colonization process.

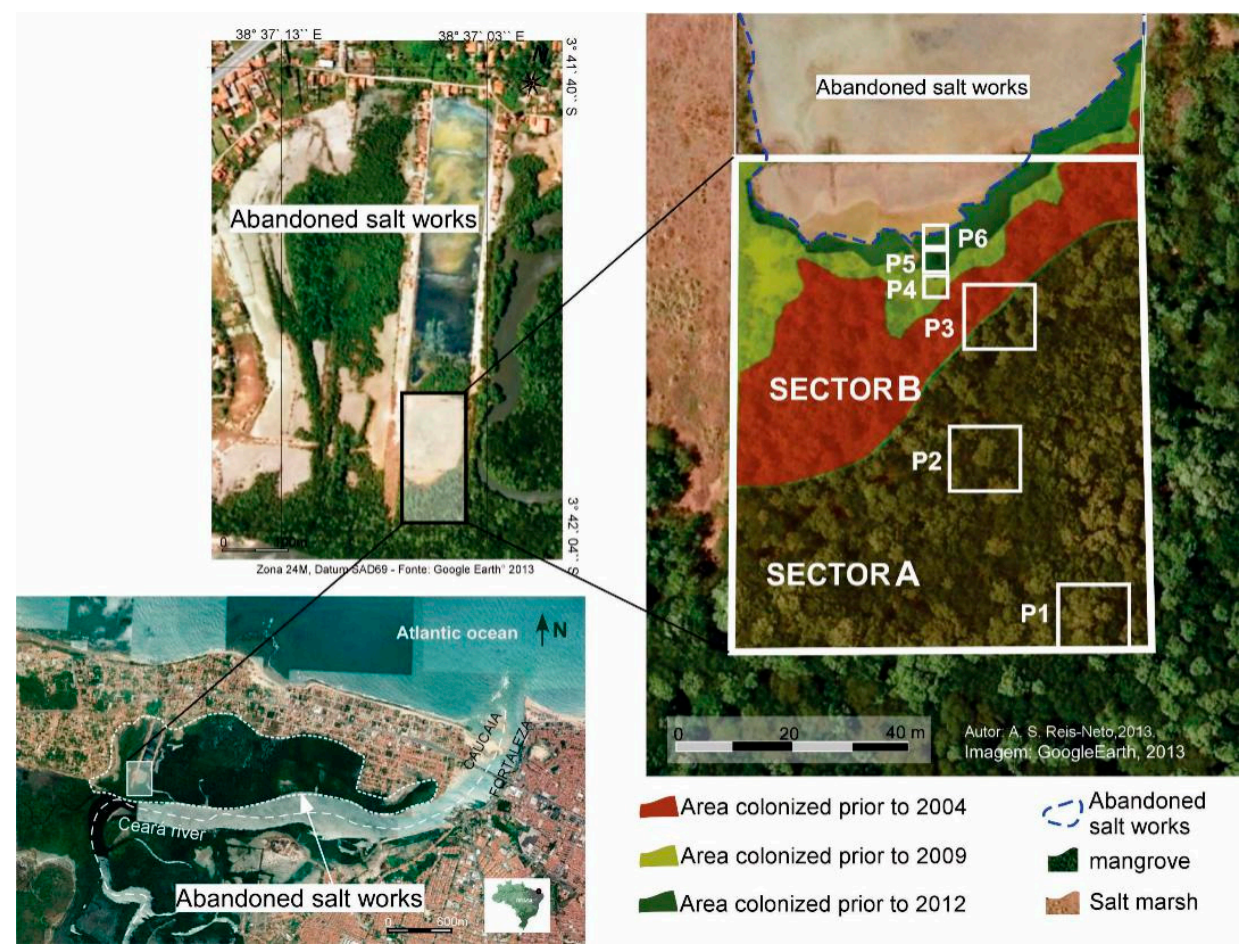

Figure 5. Identification of the different zones of expansion of the mangrove forest in an abandoned salt evaporation pond in the Margarida saltworks, between 2004 and 2012. 




Figure 6. Features of the initial expansion zone of the mangrove vegetation in the abandoned salt evaporation ponds of the Margarida saltworks in the Ceará estuary, northeastern Brazil.

\subsection{Brazilian Environmental Legislation and the Mangrove}

The first legal norms regulating the use of the resources found in Brazilian mangroves were established at the beginning of the 18th century, through a royal charter (Alvará Del Rey) issued by D. José I, which determined the protection of the mangrove trees of the captaincies (territories) of Rio de Janeiro, Pernambuco, Santos, Paraíba, Rio Grande, and Ceará [30]. However, effective public policy on the use of coastal resources was only implemented in 1965, with the establishment of the federal Forest Code, which considered mangroves to be Areas of Permanent Preservation, or APPs [31]. Since this initial step, other legal tools have been implemented for the protection of Brazilian mangroves, such as the National Coastal Management Program (Programa Nacional de Gerenciamento Costeiro: PNGC) of 1988, which prioritizes the conservation and protection of the natural resources found in the mangrove [32].

In theory, the environmental legislation that protects Brazilian mangroves is very strict, although a number of legal mechanisms can be used to relax this legislation to allow for the occupation of the mangrove ecosystem. In 2012, however, a unique mobilization was initiated on a national scale, organized by the non-governmental organization SOS Mata Atlântica, entitled "Mangrove makes a Difference" (Mangue Faz a Diferença). This social movement was motivated by the proposed changes in the federal Forest Code, which were approved by Congress, and subsequently implemented by the then president, Dilma Rousseff, through federal law number 12,651 of May 25th, 2012 [33]. These modifications were the result of efforts by the agribusiness lobby, supported by shrimp farmers, who were keen to facilitate the legal expansion of the sector into the mangrove ecosystem, principally in the Brazilian Northeast.

Between January and April 2012, a number of public campaigns and other associated activities highlighting the importance of the conservation of Brazilian mangroves were conducted in 19 Brazilian 
states and the Federal District. The "Mangrove makes a Difference" movement produced a manifesto that presents a critical analysis of the change in the forest code:

"The alteration of the Forest Code (PL 30/2011), approved by both houses of congress, represents a grave compromise of the principles, objectives, and structure of all Brazilian environmental legislation. In addition to the fundamental problems identified by scientists, environmentalists, legal specialists, and non-governmental organizations-such as the amnesty for prior infractions and the reduction of legal reserves and areas of permanent protection-we want to highlight the fact that the bill approved by the Chamber of Deputies and ratified by the Senate has a direct and profound impact on coastal and estuarine ecosystems, in particular the Brazilian mangroves, found along the whole of the country's coastline."

Research on the degradation of mangrove ecosystems has shown that this process results in a loss of the quality of life of the traditional and ethnic communities, as well as economic losses related to socio-environmental functions, such as food security and primary production [30,34-36]. This process is facilitated by the relaxation of the environmental legislation resulting from the new Forest Code.

Analysis of COEMA resolution number 02/2002.

Ceará State Council for Environmental Policy and Management (COEMA) resolution number 02/2002 regulates the licensing of shrimp farming operations in the Brazilian state of Ceará [10]. This resolution was passed with the explicit aim of protecting mangrove formations and the associated APPs, as stated explicitly in the text of the resolution. At the same time, however, this legislation also provides incentives for the development of shrimp farming, an economic activity known to be one of the principal causes of the degradation of the mangrove ecosystem, in addition to other social and environmental impacts [16], in areas of saltworks, and salt flats and marshes, demanding the preservation of only $20 \%$ of the natural ecosystem.

The legal occupation of these areas contradicts the natural recuperation and development of the mangrove ecosystem, as observed in the spatiotemporal analysis of the mangrove forest on the abandoned saltworks conducted in the present study. This supports the revision of COEMA resolution $02 / 2002$, taking into consideration the geo-environmental and ecodynamic indicators of the mangrove ecosystem, in particular those related to (i) the regeneration of the mangrove forest in areas of salt marsh and salt flat, and abandoned saltworks, and (ii) the socio-environmental dependence of traditional and ethnic communities on the exploitation of natural resources provided by estuarine systems [16].

The text of COEMA resolution 02/2002 defines saltworks as anthropogenic ecosystems with "a reduced capacity for the natural regeneration of the mangrove forest" [10]. However, this contradicts the findings of the present study, which showed that the mangrove can regenerate naturally in these areas. This process was observed in the abandoned saltworks of the Ceará estuary, where the area of mangrove forest has increased by more than 400 hectares over the past four decades. These abandoned saltworks now present very different characteristics from those of the original installations. The study also confirmed that the greater the amount of time the saltworks have been abandoned, the greater the likelihood of the recuperation of the natural environment, contradicting the affirmation of COEMA resolution $02 / 2002$. As the region's artisanal saltworks began to decline at least half a century ago, there has been sufficient time for the recruitment and recolonization of the mangrove vegetation within the Ceará estuary.

It is also possible to confirm that the exploitation of environmental resources controlled by the tide has had serious impacts, initially caused by the saltworks and, since 1998, by the installation of shrimp farms. These impacts have been further accentuated by the environmental licensing of large areas of the mangrove ecosystem for the production of shrimp [27,36], with a number of abandoned salt evaporation ponds being recuperated for shrimp farming [37]. In this context, the findings of the present study-in particular, the expansion of the mangrove vegetation within the areas of abandoned saltworks-provide an important conceptual framework for the adjustment of the legislation, which should contribute to the revitalization of the natural dynamics of the estuarine system and the expansion of the services derived from this ecosystem [21]. 
Since the 1970s, the abandoned infrastructure of the former saltworks have become increasingly encrusted in mud and subject to weathering and erosion through the action of the tides and rainy season flooding. Despite this, the mangrove vegetation has flourished within the abandoned saltworks, forming an incipient forest and colonizing new areas within the hypersaline flats. The mangrove forest has expanded, even where the soil has been made hypersaline by the evaporation ponds [38]. The hydrodynamic interactions of the tidal channels have resulted in the recruitment of mangrove propagules, which have been fixed within the abandoned salt evaporation ponds, supporting the expansion of the tree cover, and reflecting the dynamic expansion of the mangrove observed during the present study.

Abandoned or degraded saltworks (in which the levees have eroded, permitting the incursion of daily tidal oscillations) in tropical regions may be colonized naturally by mangrove forests, without financial cost. These forests can be transformed into an ecosystem with enormous economic, biological, and cultural value, supporting both direct and indirect uses, as well as maximizing their intrinsic value $[21,39,40]$.

These findings reinforce the need for the discussion of a new definition of the legislation, in the context of term "XIII-Abandoned saltworks: are areas previously converted to human use which, in the absence of human intervention, are no longer adequate for the production of salt. The soil of these areas presents residual hypersalinity and is associated with the expansion of the mangrove forest, with a favorable capacity for the natural regeneration of the mangrove vegetation. In this case, these areas should be recuperated and made fully available for the re-establishment of the natural environmental dynamics of the system, regulated by the oscillations of the tide".

\section{Conclusions}

The present study confirmed the natural regeneration of the mangrove vegetation within areas of abandoned saltworks in the semi-arid region of northeastern Brazil (Ceará state) between 1968 and 2012. The geotechnological approach adopted in this study permitted the identification and quantification of the areas of both mangrove and saltworks in the Ceara estuary. During the study period, the area of mangrove forest increased by $165 \%$, from 380.0 ha to 1006.6 ha. During the same period, the area occupied by the abandoned saltworks decreased from 621.9 ha to 226.9 ha, with the mangrove recolonizing naturally an area of approximately 408.1 ha of abandoned saltworks over a 44 year period.

To achieve the maximum potential for the regeneration of the mangrove forest in areas of abandoned saltworks of the Ceará estuary, it will still be necessary to recuperate approximately $34 \%$ of the area of the abandoned saltworks, through the degradation of the original levees, to re-establish the natural flow of the tides. This regeneration of mangrove forests, based on the increase in the total productivity of the ecosystem and its biodiversity, will support more effective management measures, particularly for the conservation of this ecosystem.

The current state resolution that regulates the environmental licensing for shrimp farming operations [16] was evaluated in the context of the findings of the present analysis of the spatiotemporal dynamics of the mangrove ecosystem of the Ceará estuary. Rather than making anthropogenic areas that were once part of the mangrove forest, including hypersaline areas of salt flat, available for the recuperation of the quality of the local environment, the resolution favors the continuity of anthropogenic impacts and the fragmentation of the ecosystem.

The insights provided by the present study into the dynamics of the mangrove ecosystem, based on a geotechnological approach, and cultural landscape analysis, contributed to the definition of the spatiotemporal evolution of the ecosystem during the natural regeneration of the mangrove forest in areas of abandoned saltworks. The analytical procedures adopted in the present study favored the compilation of a database to guide the recuperation and conservation of the mangroves of the Brazilian state of Ceará and provide insights for the eventual reformulation of the current state legislation on the environmental licensing of shrimp farming operations. 
Author Contributions: Investigation, A.S.d.R.-N., M.C.-L. and A.J.d.A.M.; Data curation, A.S.d.R.-N. Methodology, M.C.-L.; Supervision, A.J.d.A.M. and M.C.-L.; Writing-original draft, A.S.d.R.-N.; Writing-review \& editing, A.J.d.A.M. and M.C.-L.

Funding: This research received no external funding.

Acknowledgments: We are grateful to CAPES/REUNI for providing a masters stipend (Id. number 35755268851), and would also like to thank the graduate programs in Geography (PPGeo) and Development and Environment (PRODEMA) at the Federal University of Ceará (UFC), and the geoprocessing laboratory (LABOCART/UFC/PPGeo) for support with the collection and analysis of data. We would also like to thank the team of the UFC - Mangue Vivo extension program for their contribution to the fieldwork. To the Support Program for Postgraduate and Scientific and Technological Research in Socioeconomic Development in Brazil (PGPSE-CAPES 88887.123947 / 2016-00): Coastal Environmental Systems and Northeastern Economic Occupation; and the Institutional Program for Internationalization (PRINT / CAPES 88887.312019 / 2018-00): Socio-environmental technologies and methodologies integrated in territorial sustainability: community alternatives to climate change.

Conflicts of Interest: The authors declare no conflict of interest.

\section{References}

1. Giri, C.; Ochieng, E.; Tieszen, L.L.; Zhu, Z.; Singh, A.; Loveland, T.; Masek, J.; Duke, N. Status and distribution of mangrove forests of the world using earth observation satellite data. Glob. Ecol. Biogeogr. 2011, 20, 154-159. [CrossRef]

2. Feller, I.C.; Lovelock, C.E.; Berger, U.; Mckee, K.L.; Joye, S.B.; Ball, M.C. Biocomplexity in Mangrove Ecosystem. Annu. Rev. Mar. Sci. 2010, 2, 395-417. [CrossRef] [PubMed]

3. Schaeffer-Novelli, Y.; Cintrón-Molero, G.; Molero, G.; Soares, M.L.; De-Rosa, M.M.P.T. Brazilian mangroves. Aquat. Ecosyst. Health Manag. 2000, 3, 561-570. [CrossRef]

4. Jablonski, S.; Filet, M. Coastal management in Brazil-A political riddle. Ocean Coast Manag. 2008, 51, 536-543. [CrossRef]

5. ICMBio. Atlas dos Manguezais Brasileiros; ICMBio: Brasília, Brasil, 2018; p. 176.

6. Schaeffer-Novelli, Y.; Cintrón-Molero, G.; Camargo, R.R.A.T.M. Variability of Mangrove Ecosystem along the Brazilian Coast. Estuar. Res. Fed. 1990, 13, 204-218. [CrossRef]

7. Rocha, R.M.; Da Silva, C.D.F.; De Lucena, F.M.A.; Bezerra, R.M.; De Medeiros, D.H.M.; Da Silva, A.M.A.; De Araújo, C.N.; Xavier-Filho, L. Tropical solar saltworks-influence and challenges in the coexistence with traditional population in the Brazilian northeast region. In Proceedings of the 9th International Symposium on Salt, Beijing, China, 4-7 September 2009; p. 4-1.

8. Maia, M.T.A. Circuito Espacial de Produção de Sal: O uso do Território do Município de Macau/RN Pelas Indústrias Salineiras. Master's Thesis, Universidade Federal do Rio Grande do Norte, Natal, Brazil, 2011; p. 161.

9. Da Silva Costa, D.F.; Adailson da Silva, A.; Miranda Medeiros, D.H.; Araújo Lucena Filho, M.; De Medeiros Rocha, R.; Lillebo, A.I.; Soares, A.M. Breve revisão sobre a evolução histórica da atividade salineira no Estado do Rio Grande do Norte (Brasil). Soc. Nat. 2013, 25, 21-34. [CrossRef]

10. Resolução do Conselho Estadual do Meio Ambiente (COEMA). Resolução $n^{\circ}$ 02/2002. Estabelece as Normas Regulamentadoras dos Procedimentos de Licenciamento Environmental para Empreendimentos de Carcinicultura Terrestre; Publicada em Diário Oficial (DOE): Fortaleza, CE, Brazil, 2002.

11. Lacerda, L.D.; Menezes, M.O.T.; Molisani, M.M. Changes in mangrove extension at the Pacoti River estuary, Ce, NE Brazil due to regional environmental changes between 1958 and 2004. Biota Neotrop. 2007, 7, 67-72. [CrossRef]

12. Meireles, A.J.A.; Silva, E.V.; Thiers, P.R.L.T. Impactos Ambientais das atividades de carcinicultura no ecossistema Manguezal do Estado do Ceará, Nordeste do Brasil. Rev. Gest. Costeira Integr. 2010, 2, 1-11.

13. Reis-Neto, A.S.; Cunha-Lignon, M.; Arruda-Reis, M.C.C.; Meireles, A.J.A. The Ceara River Mangrove's landscape (northeast Brazil): Comparative analyses of 1968 and 2009. J. Coast. Res. 2011, 2, 1802-1805.

14. Reis-Neto, A.S.; Meireles, A.J.A.; Cunha-Lignon, M. Analyses of the mangrove's rehabilitation process in abandoned saltwork area, in the Ceará river, Northeast Brazil. Int. J. Appl. Nat. Sci. 2013, 2, 27-35.

15. Constanza, R.; D’arge, R.; De Groot, R.S.; Farber, S.; Grasso, M.; Hannon, B.; Limburg, K.; Naeem, S.; O'neill, R.V.; Paruelo, J.; et al. The value of the world's ecosystem services and natural capital. Nature 1997, 387, 253-260. [CrossRef] 
16. Queiroz, L.S.; Rossi, S.; Calvet-Mir, L.; Ruiz-Mallen, I.; Garcia-Betorz, S.; Salva-Prat, J.; Meireles, A.J.A. Neglected ecosystem services: Highlighting the socio-cultural perception of mangroves in decision-making processes. Ecosyst. Serv. 2017, 26, 137-145. [CrossRef]

17. Molisani, M.M.; Cruz, A.L.V.; Maia, L.P. Estimativa da descarga fluvial para os estuários do Estado do Ceará. Bras. Arq. Ciênc. Mar 2006, 39, 53-60.

18. Funceme-Fundação Cearense de Meteorologia e Recursos Hidricos. Previsão de Afluências. Available online: http:/ / www.funceme.br/index.php/29-produtos-e-servicos/previs\%C3\%A3o/hidrol\%C3\%B3gico/ 419-previsao-sazonal-de-afluencias (accessed on 21 July 2012).

19. Martins, E.S.P.R.; Vasconcelos Júnior, S.C. O clima da Região Nordeste entre 2009 e 2017: Monitoramento e previsão. Parcer. Estratég. 2017, 22, 63-80.

20. Guedes, R.L.; Andreoli, R.V.; Kayano, M.T.; Oyama, M.D.; Alves, M.A.S. Série Temporal de precipitação mensalt em Fortaleza, Brasil: Comparação entre observações e dados de reanalysis do NCEP/NCAR. Rev. Bras. Metereol. 2005, 20, 83-92.

21. de Andrade Meireles, A.J.; Campos, A.A. Componentes Geomorfológicos, Funções e Serviços Environmental de Complexos Estuarinos no Nordeste do Brasil. Rev. Assoc. Nac. Pós-Grad. Pesqui. Geogr. 2010, 4, 89-107.

22. Heumann, B.W. Satellite remote sensing of mangrove forest: Recent advances and future opportunities. Prog. Phys. Geogr. 2011, 35, 87-108. [CrossRef]

23. Freitas, D.M.; Tagliani, P.R.A. The use of GIS for the integration of traditional and scientific knowledge in supporting artisanal fisheries management in Southern Brazil. J. Environ. Manag. 2009, 90, 2071-2080. [CrossRef] [PubMed]

24. Jensen, J.R. Remote Sensing of the Environment: An Earth Resource Perspective, 2nd ed.; Pearson: Boulder, CO, USA, 2007.

25. Cunha-Lignon, M.; Menghini, R.P.; Santos, L.C.M.; Niemeyer-Dinóla, C.; Scharffer-Novelli, Y. Estudos de caso nos manguezais do Estado de São Paulo (Brasil): Aplicação de Ferramentas com diferentes escalas Espaçotemporais. Rev. Gest. Costeira 2009, 9, 79-91. [CrossRef]

26. Schaeffer-Novelli, Y.; Vale, C.C.; Cintrón, G. Monitoramento do Ecossistema Manguezal: Estrutura e características funcionais. In Protocolos de Campo para o Monitoramento de Habitats Bentônicos Costeiros: Rede de Monitoramento de Habitats Bentônicos Costeiros—ReBentos; Turra, A., Dedanai, M.R., Eds.; IOUSP: São Paulo, SP, Brazil, 2015; Chapter 4; pp. 65-83. 255p.

27. Meireles, A.J.A.; Cassola, R.S.; Tupinambá, S.V.; de Queroz, L.S. Impactos environmental decorrentes das atividades da carcinicultura ao longo do litoral cearense, nordeste do Brasil. Rev. Mercat. 2007, 1, 83-106.

28. Elster, C.; Perdomo, L. Rooting and vegetative propagation in Laguncularia racemosa. Aquat. Bot. 1999, 163, 83-93. [CrossRef]

29. Rovai, A.S.; Soriano-Sierra, E.J.; Pagliosa, P.R.; Cintrón, G.; Schaeffer-Novelli, Y.; Menghini, R.P.; Coelho, C., Jr.; Horta, P.A.; Lewis, R.R., III; Simonassi, J.C.; et al. Secondary sucession impairment in restored mangroves. Wetl. Ecol. Manag. 2012, 20, 447-459. [CrossRef]

30. Field, C.B.; Osborn, J.G.; Hoffman, L.L.; Polsenberg, J.F.; Ackerly, D.D.; Berry, J.A.; Björkman, O.; Held, A.; Matson, P.A.; Mooney, H.A. Mangrove biodiversity and ecosystem function. Glob. Ecol. Biogeogr. Lett. 1998, 7, 3-14. [CrossRef]

31. BRASIL. Lei Federal no 4.771, de 15 de Setembro de 1965, que Institui o Código Florestal Brasileiro; Publicada no Diário Oficial da União: Brasília, DF, Brasil, 1965.

32. BRASIL. Lei Federal $n^{0}$ 7.661, de 16 de Maio de 1988, que Institui o Plano Nacional de Gerenciamento da Zona Costeira (PNGC); Publicada no Diário Oficial da União: Brasília, DF, Brasil, 1988.

33. BRASIL. Lei Federal no 12.651, de 25 de Maio de 2012, que Institui o Código Florestal Brasileiro; Publicada no Diário Oficial da União: Brasília, DF, Brasil, 2012.

34. FAO. The World's Mangroves 1980-2005; FAO Forestry Paper 153; FAO: Rome, Italy, 2007; 78p.

35. Kumar, P. The Economics of Ecosystems and Biodiversity: Ecological and Economic Foundations; An output of TEEB: The Economics of Ecosystems and Biodiversity; Earthscan: London, UK, 2010; 410p.

36. Queiroz, L.S.; Rossi, S.; Meireles, A.J.A.; Coelho, C. Shrimp aquaculture in the federal state of Ceará, 1970-2012: Trends after mangrove forest privatization in Brazil. Ocean Coast. Manag. 2013, 73, 54-62. [CrossRef]

37. IBAMA-Instituto Brasileiro do Meio Ambiente e Recursos Renováveis. Diagnóstico da Carcinicultura no Estado do Ceará, Relatório Final; Diretoria de Proteção Environmental (DIPRO), Diretoria de Licenciamento e 
Qualidade Environmental (DILIQ) e Gerência Executiva do Ceará (GEREX-CE): Fortaleza, CE, Brasil, 2005; Volume I, 177p.

38. Albuquerque, A.G.B.M.; Ferreira, T.O.; Nóbrega, G.N.; Romero, R.E.; Júnior, V.S.; Meireles, A.J.A.; Otero, X.L. Soil genesis on hypersaline tidal flats (apicum ecosystem) in a tropical semi-arid estuary (Ceará, Brazil). Soil Res. 2014, 52, 140-154. [CrossRef]

39. Barbier, E.B.; Strand, I. Valuing mangrove fishery linkages: A case study of Campeche, Mexico. Environ. Resour. Econ. 1998, 12, 151-166. [CrossRef]

40. Mäler, K.G.; Aniyar, S.; Jansson, A. Accounting for ecosystem services as a way to understand the requirements for sustainable development. Proc. Natl. Acad. Sci. USA 2008, 105, 9501-9506. [CrossRef] [PubMed]

(C) 2019 by the authors. Licensee MDPI, Basel, Switzerland. This article is an open access article distributed under the terms and conditions of the Creative Commons Attribution (CC BY) license (http:/ / creativecommons.org/licenses/by/4.0/). 